\section{Ordforklaringer}

IVF: In vitro-fertilisering. «Prøverørsbehandling» med befruktning utenfor kroppen. Naturlig syklus IVF er in vitrofertilisering uten hormonstimulering.

ICSI: Intracytoplasmatisk spermieinjeksjon eller mikroinjeksjonsbehandling. Befruktning utenfor kroppen hvor en sædcelle føres direkte inn i egget.

Endometriose: Funksjonelt, østrogenavhengig livmorslimhinnevev som befinner seg utenfor livmoren og som fremkaller en inflammatorisk (betennelses-) reaksjon.
Multippel sklerose: Er en kronisk sykdom i sentralnervesystemet. Den rammer unge voksne, og som ved andre ikke-helbredelige sykdommer blir dermed lindring av symptomer for å bedre livskvaliteten det sentrale.

Fatigue: Kan defineres som en uforklarlig altoverskyggende tretthet, en mangel på energi eller følelse av utmattelse. Opplevelsen er subjektiv og interfererer med arbeid og daglige aktiviteter.

Se oversikt over doktoravhandlinger i seksjonen Oss imellom på side 2077

\title{
Behandlingsmetoder ved ufrivillig barnløshet
}

\author{
Forskning ved Oslo universitetssykehus, Rikshospitalet viser at prøve- \\ rørsbehandling uten hormonstimulering er egnet ved endometriose- \\ assosiert barnløshet, men ikke ved uforklarlig barnløshet.
}

Behandlingsmetodene ved assistert befruktning har stor betydning for resultatene, og må vurderes for hvert enkelt par. Anne Omland har sett på hvilke metoder som egner seg best ved uforklarlig barnløshet (UI) og minimal eller mild endometrioseassosiert barnløshet (EI). - Ulike metoder gir forskjeller både i graviditetsrate, antall tidlige aborter, og andel av flerlingsvangerskap i de ulike gruppene. Inseminasjon ga høyere graviditetsrate ved uforklarlig barnløshet enn ved endometrioseassosiert barnløshet, men også høyere andel flerlingsvangerskap.

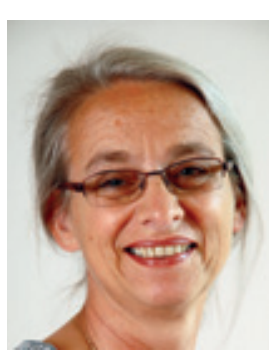

Anne Omland. Foto privat Naturlig syklus in vitro-fertilisering (IVF) ga en graviditetsrate på ca. $8,7 \%$ i UI-gruppen, sammenliknet med $23,5 \%$ i EI- og $16 \%$ i kontrollgruppen med defekte eggledere, altså signifikant bedre resultater i de to siste gruppene.
Behandling med in vitro-fertilisering og intracytoplasmatisk spermieinjeksjon (ICSI) ga bedre resultater ved uforklarlig barnløshet enn ved endometrioseassosiert barnløshet, sier Omland. Hun og hennes kolleger anbefaler inseminasjon som førstevalg ved uforklarlig barnløshet, etterfulgt av in vitro-fertilisering og ev. intracytoplasmatisk spermieinjeksjon hvis in vitro-fertilisering ikke gir befruktning. Ved endometrioseassosiert barnløshet anbefales først et begrenset antall inseminasjonsforsøk fordi behandlingen er relativt enkel, deretter naturlig syklus in vitro-fertilisering eller in vitro-fertilisering, og ev. intracytoplasmatisk spermieinjeksjon.

Omland forsvarte avhandlingen Assisted reproductive techniques in unexplained and minimal/mild endometriosis-associated infertility for ph.d.-graden ved Universitetet i Oslo 22.8. 2009.

\section{Anne Forus}

anneforu@online.no

Tidsskriftet

\section{- Må få smertebehandling}

\section{Smerte og angst er underdiagnostisert hos pasienter med multippel sklerose, og bare en tredel av pasientene får behandling for smer- tene sine.}

I sin avhandling Non-motor symptoms in multiple sclerosis har Antonie Giæver Beiske bl.a. undersøkt hvilke symptomer pasienter med multippel sklerose har i tillegg til de motoriske, og hva slags behandlingstilbud de får. $40 \%$ av pasientene oppga at smerte hadde stor innvirkning på dagliglivet, men bare en tredel av dem fikk behandling for smertene. Tretthet, angst og depresjon har også stor innvirkning på livskvaliteten. $50 \%$ av pasientene oppga at de hadde depresjon eller angst. $24 \%$ fikk behandling og hele $18 \%$ sa de ville hatt, men fikk ikke.

- Det er svært alvorlig at mange av pasientene ikke får behandling for sterke smerter og angst, særlig når vi vet at forekomsten av selvmord er økt i denne pasientgruppen. Mange leger mener at pasienter med multippel sklerose må tåle å ha litt smerter, men det er feil.
De er like behandlingstrengende, og har like god nytte av behandlingen som andre pasienter med smerter eller angst, sier Beiske.

Hun har også undersøkt hvordan fysioterapi påvirker utmattelse (fatigue). Etter et fire ukers behandlingsopphold var de fleste pasientene mindre plaget med dette. Men dette skyldtes bedring av livskvaliteten som følge av oppholdet, mer enn selve behandlingen. Beiske mener leger bør bli mer oppmerksomme på ikkemotoriske plager hos disse pasientene.

- Vi må ikke bare konsentrere oss om hvor mange meter de kan gå, sier hun.

Beiske disputerte for ph.d.-graden ved Universitetet i Oslo 26.6. 2009.

\section{Eline Feiring}

eline.feiring@legeforeningen.no

Tidsskriftet 